\title{
DNA damage in Wistar Kyoto rats exercised during pregnancy $^{1}$
}

\author{
Mikaela da Silva Corrêa', Rafael Bottaro Gelaleti", Giovana Fernanda Bento"', Débora Cristina Dama- \\ sceno'v $^{\text {, }}$ José Carlos Peraçoliv
}

\begin{abstract}
'Fellow Master degree, Postgraduate Program in Ginecology, Obstetrics and Mastology, Department of Gynecology and Obstetrics, Laboratory of Experimental Research in Gynecology and Obstetrics, Botucatu Medical School, Universidade Estadual Paulista (UNESP), Botucatu-SP, Brazil. Scientific, intellectual, conception and design of the study; acquisition, analysis and interpretation of data; technical procedures; manuscript preparation.

"Fellow PhD degree, Postgraduate Program in Ginecology, Obstetrics and Mastology, Department of Gynecology and Obstetrics, Laboratory of Experimental Research in Gynecology and Obstetrics, Botucatu Medical School, UNESP, Botucatu-SP, Brazil. Scientific and intellectual content of the study, analysis and interpretation of data, technical procedures, statistics analysis, manuscript preparation, critical revision.

I"Graduate student, Botucatu Medical School, UNESP, Botucatu-SP, Brazil. Scientific and intellectual content of the study, acquisition of data, technical procedures.

IVFull Professor, CNPq Researcher Followship 2, Postgraduate Program in Ginecology, Obstetrics and Mastology, Department of Gynecology and Obstetrics, Laboratory of Experimental Research in Gynecology and Obstetrics, Botucatu Medical School, UNESP, Botucatu-SP, Brazil. Scientific, intellectual, conception and design of the study; analysis and interpretation of data; statistics analysis; manuscript preparation; critical revision; final approval.

${ }^{\vee}$ Full Professor and Head, CNPq Researcher Fellowship 2, Postgraduate Program in Ginecology, Obstetrics and Mastology, Department of Gynecology and Obstetrics, Laboratory of Experimental Research in Gynecology and Obstetrics, Botucatu Medical School, UNESP, Botucatu-SP, Brazil. Scientific, intellectual, conception and design of the study; analysis and interpretation of data; critical revision; final approval.
\end{abstract}

\section{Abstract}

Purpose: To evaluate DNA damage levels in pregnant rats undergoing a treadmill exercise program.

Methods: Wistar Kyoto rats were allocated into two groups ( $n=5$ animals/group): non-exercise and exercise. The pregnant rats were underwent an exercise protocol on a treadmill throughout pregnancy. Exercise intensity was set at 50\% of maximal capacity during maximal exercise testing performed before mating. Body weight, blood pressure and glucose levels, and triglyceride concentration were measured during pregnancy. At day 10 post-natal, the animals were euthanized and maternal blood samples were collected for DNA damage.

Results: Blood pressure and glucose levels and biochemical measurements showed no significant differences. Increased DNA damage levels were found in exercise group compared to those of non-exercise group ( $p<0.05)$.

Conclusion: The exercise intensity protocol used in the study might have been exhaustive leading to maternal increased DNA damage levels, demonstrating the relevance of an adequate protocol of physical exercise.

Key words: Pregnancy. Exercise. DNA Damage. Rats. 


\section{Introduction}

Animal studies have shown that normal fetal growth is critically dependent on adequate intrauterine environment because maternal metabolic abnormalities impair homeostasis, which might predispose development of disease in adulthood ${ }^{1}$.

Pregnancy is per se an inflammatory condition with increased susceptibility to oxidative stress ${ }^{2}$. Reactive oxygen and nitrogen species, derived from the inflammatory process, can cause DNA damage that might affect several physiological processes during pregnancy. As repair of DNA damage is suppressed during pregnancy, pregnant women become more susceptible to environmental and endogenous agents $^{3}$. Furthermore, modern sedentary lifestyles can also cause excess inflammation and oxidative stress, which increases the risk of diseases and DNA damage ${ }^{4}$.

Physical activity brings health benefits, so pregnant women are advised to keep active during pregnancy, although a large number of them stop exercising when they are pregnant ${ }^{5}$. Physical fitness and regular prenatal exercise can enhance placental growth and vascularity, decrease oxidative stress and reduce maternal endothelial dysfunction ${ }^{6}$. Nonetheless, the American College of Obstetricians and Gynecologists $^{7}$ recommends that in order to ensure safety of both mother and fetus, exercise intensity should be closely monitored during pregnancy. Better benefits are directly associated with higher levels of physical activity, but depending on its intensity, exercise can either prevent or cause DNA damage ${ }^{8}$. The underlying mechanisms are still unclear. Although some studies have evaluated the influence of exercise intensity on oxidative stress during pregnancy ${ }^{9}$, the effects of physical activity on DNA damage remain without further investigation. Thus, the aim of this study was to evaluate DNA damage levels in pregnant Wistar Kyoto rats under a treadmill exercise program.

\section{Methods}

The Ethics Committee for Animal Research of Botucatu Medical SchoolUniversidade Estadual Paulista approved the protocols of this study (CEEA Number 889/2011).

Virgin female and male Wistar Kyoto (WKY) rats were acquired from the animal colony of Universidade de São Paulo and kept at the Laboratory of Experimental Research of the Department of Internal Medicine, Botucatu Medical School, UNESP, under controlled temperature $\left(22 \pm 2^{\circ} \mathrm{C}\right)$ and lighting $(12 \mathrm{~h}$ light/12h dark cycle) with free access to food and water.

Female rats were randomly assigned in two experimental groups ( $n=5$ animals/ group): non-exercise WKY - pregnant rats were submitted to no physical exercise, and exercise WKY- pregnant rats submitted to treadmill walking.

\section{Adaptation to treadmill walking}

At adult life (approximately at 80 days of life), the animals from the exercise group were familiarized with the exercise apparatus by being placed on the treadmill operating at zero speed as a mild electric stimulation and noise. Subsequently, familiarization to treadmill walking was performed at 5 meter $(\mathrm{m}) /$ minutes ( $\mathrm{min}$ ) for $10 \mathrm{~min}$ over a 1-week period. Electric stimulation was used to encourage and improve the ability to walk throughout the adaptation period. During pregnancy this stimulus was not carried out. Non-exercise rats were not submitted to a treadmill walking and were kept at the same inverted dark-light cycle to reproduce the circadian biological clock of animals.

\section{Maximal exercise testing}

Following familiarization to training, two days before mating, exercise animals were underwent to maximal exercise testing, which 
is widely used to determine exercise intensity in experimental studies ${ }^{10}$. The test consisted of graded exercise on the treadmill, starting at 5 $\mathrm{km} / \mathrm{h}$ with increments of $0.3 \mathrm{~km} / \mathrm{h}$ every $3 \mathrm{~min}$ up to exhaustion ${ }^{11}$. Low intensity exercise was set at $50 \%-60 \%$ of the speed reached during maximal exercise test prior to pregnancy ${ }^{10}$.

\section{Mating}

At approximately 90 days of life, every morning males and females rats were put in breeding cages for mating. By late afternoon, the male was removed and vaginal smears were taken from the females for examination under a light microscope. The presence of spermatozoa in vaginal smears was positive mating indicator, and this was designated as day zero of pregnancy. Following, the animals were weighed, and the blood pressure was measured. The pregnant rats were housed in individual cages during whole pregnancy.

\section{Treadmill exercise during pregnancy}

The pregnant rats were submitted to a motorized treadmill started on day 1 of pregnancy at $10 \mathrm{~m} / \mathrm{min}$ for $20 \mathrm{~min}$, with increments of $10 \mathrm{~min}$ every two days up to 60 min. Thereafter, 60-minute sessions were held up to the end of pregnancy. Speed was gradually increased by $1 \mathrm{~m} / \mathrm{min}$ every day until maximum (13 $\mathrm{m} / \mathrm{min}$ - determined by maximum exercise testing).

\section{At pregnancy_maternal analysis}

At days $0,7,14$ and 21 of pregnancy, maternal body weight was assessed for weight gain evaluation, and systolic blood pressure level was measured in conscious rats by indirect tail-cuff plethysmography (LE5001 Pressure Meter; Panlab ${ }^{\star}$, Barcelona, Spain). At days 0,14 and 20 of pregnancy, blood samples were obtained by tail cut for triglyceride level measurement (Accutrend ${ }^{\bullet}$ Plus, Roche Diagnostics $\mathrm{GmbH}$, Mannheim, Germany) and blood glucose levels (One-Touch Ultra, Johnson
\& Johnson ${ }^{\oplus}$ ).

\section{At day 10 post-partum_maternal analysis}

At term pregnancy, the rats were closely monitored for newborn birth. Ten days after birth, mothers and pups were euthanized under sodium pentobartbital (Hypnol $^{\circ}$, Cristália Chemicals, Brazil) and decapitated for collection of whole blood samples. $500 \mu \mathrm{L}$ were collected in EDTA vacutainer tubes and transferred to microtubes containing $400 \mathrm{~mL}$ of RPMI 1640 medium and $100 \mathrm{~mL}$ of dimethyl sulfoxide (DMSO, Sigma-Aldrich ${ }^{\circ}$ ). The samples were kept at $-20^{\circ} \mathrm{C}$ for $24 \mathrm{~h}$, and then stored in a $-80^{\circ} \mathrm{C}$ freezer. Thawing was achieved on a $37^{\circ} \mathrm{C}$ water bath, and pellets were washed with PBS. A $20-\mathrm{ml}$ aliquot was mixed with $120 \mathrm{ml}$ low melting point (LMP) agarose, immersed into a Iysis solution, electrophoresed, neutralized and stained for DNA damage assessment.

\section{Comet assay}

\section{Chemicals}

Normal Melting Point Agarose (NMPA) and Low Melting Point Agarose (LMPA) ${ }^{12}$ (Collins 2004), sodium chloride ( $\mathrm{NaCL})$, ethidium bromide, dimethyl sulfoxide (DMSO), sodium ethylene diamine tetra-acetic acid (EDTA), hydrochloric Acid $(\mathrm{HCl})$, sodium hydroxide $(\mathrm{NaOH}), \mathrm{N}$-lauroyl sarcosine, Calcium (Ca2+) and Magnesium (Mg2+)-Free phosphatebuffered saline (PBS), Tris and Triton X-100.

\section{Treatment with hydrogen peroxide $\underline{H}_{\underline{2}} \underline{O}_{2} L$}

Treatment with $\mathrm{H}_{2} \mathrm{O}_{2}(400 \mu \mathrm{M})$ was used to create positive controls, according to the protocol described by Blasiak et al. ${ }^{13}$ with modification regarding the molarity to the $\mathrm{H}_{2} \mathrm{O}_{2}$ solution $(10 \mu \mathrm{M})$.

\section{Electrophoresis}

The comet assay was conducted as described by Tice et al. ${ }^{14}$ with modification ${ }^{15}$. 
Slides with test-samples were placed in an electrophoresis chamber and incubated with $\mathrm{NaOH} /$ EDTA buffer solution for $20 \mathrm{~min}$ at $4^{\circ} \mathrm{C}$. Electrophoresis was run at 25 volts ( $300 \mathrm{~mA})$ for $30 \mathrm{~min}$. Subsequently, the slides were neutralized in Tris ( $\mathrm{pH}=7.5)$ for $15 \mathrm{~min}$, fixed in $100 \%$ ethanol, and dried at room temperature.

\section{Staining}

All slides were stained with ethidium bromide $(20 \mathrm{mg} / \mathrm{mL})$, coated with a coverslip, and immediately analyzed.

\section{Slide analysis}

Slide samples were examined considering 5 different classes of DNA damage according to a visual score system, on a 0-4 scale ( $0=$ no damage, $4=$ maximum damage). A total of 100 nucleoids per sample were analyzed. Each nucleoid analyzed received a score ranging from zero to 4 according to its characteristics. In addition, comet observations were made at $x 400$ magnification using a fluorescence microscope. One hundred nucleoids per sample (50/slide) were assessed by automated image analysis (Comet Assay IV, Perceptive Instruments, UK). Tail intensity (defined as the percentage of DNA in the tail) was used as a measure of DNA damage.

\section{Statistical analysis}

Analysis of variance (ANOVA) followed by Student's t test was used for the analysis of the study population. DNA damage levels were assessed by the Wilcoxon two-sample test. The level of statistical significance adopted was $p<0.05$

\section{Results}

During pregnancy, maternal body weight, systolic pressure, blood glucose and triglyceride levels, and heart weight showed no significant statistically difference between the exercise and the non-exercise groups ( $p>0.05$ ). In addition, the mean number of live newborns of exercise group did no differ compared to that of non-exercise rats (Table 1 ).

Table 1 - Characteristics of the study groups during pregnancy (days 0, 7, 14 and 20) and day 10 post-partum of non-exercise and exercise Wistar Kyoto rats.

\begin{tabular}{|c|c|c|}
\hline & NON-EXERCISE & EXERCISE \\
\hline \multicolumn{3}{|l|}{$\begin{array}{l}\text { Body } \\
\text { weight (g) }\end{array}$} \\
\hline Day 0 & $198.3 \pm 10.35$ & $213.4 \pm 9.56$ \\
\hline Day 7 & $213.6 \pm 8.07$ & $218.3 \pm 10.71$ \\
\hline Day 14 & $230.0 \pm 7.96$ & $242.2 \pm 11.15$ \\
\hline Day 20 & $267.5 \pm 9.20$ & $288.0 \pm 22.49$ \\
\hline $\begin{array}{l}\text { Day } 10 \\
\text { post-partum }\end{array}$ & $234.7 \pm 4.34$ & $224.5 \pm 41.57$ \\
\hline \multicolumn{3}{|c|}{$\begin{array}{l}\text { Systolic } \\
\text { pressure level } \\
(\mathrm{mmHg})\end{array}$} \\
\hline Day 0 & $121.80 \pm 4.09$ & $130.50 \pm 16.78$ \\
\hline Day 7 & $120.80 \pm 2.28$ & $125.33 \pm 6.66$ \\
\hline Day 14 & $113.40 \pm 7.16$ & $118.33 \pm 5.51$ \\
\hline Day 20 & $112.75 \pm 5.91$ & $115.67 \pm 6.66$ \\
\hline \multicolumn{3}{|c|}{$\begin{array}{l}\text { Blood glucose } \\
\text { level (mg/dL) }\end{array}$} \\
\hline Day 0 & $129.25 \pm 57.27$ & $107.25 \pm 4.72$ \\
\hline Day 7 & $115.20 \pm 13.52$ & $108.50 \pm 14.48$ \\
\hline Day 14 & $82.33 \pm 8.62$ & $102.50 \pm 12.29$ \\
\hline Day 20 & $84.60 \pm 12.78$ & $85.67 \pm 7.23$ \\
\hline \multicolumn{3}{|l|}{$\begin{array}{l}\text { Triglyceride } \\
\text { level (mg/dL) }\end{array}$} \\
\hline Day 0 & $98.25 \pm 18.96$ & $98.75 \pm 7.68$ \\
\hline Day 14 & $144 \pm 16.97$ & $138 \pm 19.82$ \\
\hline Day 20 & $178.33 \pm 109.56$ & $136 \pm 46.67$ \\
\hline \multicolumn{3}{|c|}{$\begin{array}{l}\text { Number of } \\
\text { live newborns }\end{array}$} \\
\hline $\begin{array}{l}\text { Day } 10 \\
\text { post-partum }\end{array}$ & $9.0 \pm 2.01$ & $11.33 \pm 1.53$ \\
\hline
\end{tabular}


Figure 1 shows maternal DNA damage levels. The exercise group presented higher DNA damage levels compared to those of nonexercise rats $(p<0.05)$. The DNA damage levels showed no significant correlation with body weight, systolic pressure, blood glucose and triglyceride levels) ( $p>0.05$ ) (data not shown).

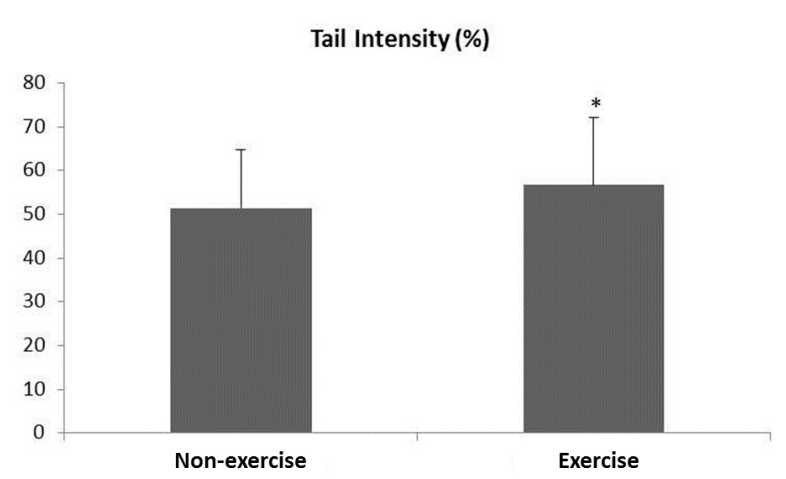

Figure 1 - DNA damage levels of non-exercise and exercise Wistar Kyoto rats at day 10 post-partum. Data reported as mean \pm standard deviation. ${ }^{*} p<0.05$ - compared to non-exercise group (Wilcoxon two-sample test).

\section{- Discussion}

Physical training during pregnancy in laboratory animals has been shown to influence fetal growth and to improve maternal metabolism in models of voluntary exercise ${ }^{16}$ and swimming ${ }^{17}$. However, such exercise models do not allow standardizing exercise intensity for animals, even if they are not pregnant. Therefore, the motorized treadmill has been used for establishing exercise duration/intensity, and the direct effect of the preferred intensity ${ }^{18}$.

Our results show that treadmill training did not affect pregnancy or fetal viability. Indeed, maternal body weight, systolic pressure, blood glucose and triglyceride levels showed no differences between experimental groups. Other studies have yielded conflicting results with regard to maternal body weight gain and fetal growth. These results might to be explained due to differences on exercise intensity, duration and type as well as to the presence/absence of preconditioning or familiarization with the type of exercise employed $^{19}$. Some animal studies have suggested that, in contrast to exercise of low to-moderate intensity, strenuous exercise may affect fetal and maternal body weight gain ${ }^{20}$. However, others have reported no effect on either maternal body weight gain ${ }^{21}$ or fetal body weight ${ }^{22}$.

Although the exercise type used in our study did not affect the maternal reproductive and offspring number, there was an increased DNA damage levels in the exercise group. In this group, maximal exercise testing was performed before mating, indicating the estimated capacity for low intensity training before pregnancy might be different of that applied during pregnancy. According to Veja et al. ${ }^{23}$, the pregnant rats submitted to voluntary exercise showed reduced physical capacity as pregnancy advanced. Thus, it is possible that the exercise intensity used in our study, which was classified as low at early pregnancy, was strenuous during pregnancy, and might therefore be linked to the increased maternal DNA damage levels. This hypothesis is supported by the fact that physical training of moderate intensity has been reported to provide protection against free radical generation in the long term due to an adaptive mechanism to meet energy demands ${ }^{24}$ that modulates oxidative responses, which become more effective with time. Nonetheless, in the event of overtraining, the homeostatic balance may be altered and to impair hormonal, metabolic and immune functions ${ }^{25}$. DNA damage levels do not increase after low-to-moderate physical exercise, but can be induced by strenuous exercise in rats ${ }^{18}$. Exhaustive exercise can lead to blood flow misdistribution, contributing to increased free radical production. Excess production of 
endogenous oxidants leads to tissue and DNA damage ${ }^{26}$.

The increased levels of DNA damage observed in the exercise group have also been reported in other experiments. In a study of Sprague-Dawley rats exercising $30 \mathrm{~min} /$ day on a treadmill for eight weeks, DNA damage was significantly higher as compared to sedentary controls. However, in rats receiving supplementation with vitamin $E$, exerciseinduced DNA damage clearly was reduced, but it persisted higher than in sedentary animals ${ }^{27}$. Pereira et al. ${ }^{18}$ examined the effects of aerobic training (60\% maximal capacity) and overtraining ( $90 \%$ maximal capacity) in Swiss mice and found increased DNA damage in peripheral blood and skeletal muscle cells in the overtrained group as compared to the aerobic training group .

Strenuous exercise-induced DNA damage has been investigated with conflicting results. Our finding of increased DNA damage after exercising is consistent with those reported in human ${ }^{28}$ and animal studies ${ }^{18}$. Nonetheless, it is noteworthy that, in such studies, DNA damage levels were measured either immediately following exhaustive exercising or later. In the latter case, damage reversal was found to occur after $72 \mathrm{~h}$ of rest ${ }^{28}$, whereas in our study DNA damage levels were still increased 10 days after exercising.

Tsai et al. ${ }^{29}$ assessing oxidative DNA damage in peripheral blood mononuclear cells from 12 male runners completing a 42$\mathrm{km}$ marathon race ( $3 \mathrm{~h}$ median running time) observed a significantly increased level of oxidative DNA damage that persisted for more than one week after the race. The authors pointed out the exact mechanisms underlying this phenomenon required elucidation as their findings, as well as ours, contradict other studies reporting decreased damage levels following a $72 \mathrm{~h}$ post exercise rest ${ }^{18}$. According to those authors, the duration and extent of DNA effects seemed to increase synchronously with the amount and intensity of exercise. Furthermore, the fact that substantial increase in DNA damage still occurred in the subjects of their study, who undertook regular running training contradicts the notion that regular training confers protection against further exercise-induced DNA damage caused by adaptive responses ${ }^{29}$.

Gandhi \& Gunjan ${ }^{26}$ in their study review suggested the delayed onset of DNA damage might be explained by the fact that the initial injury is mechanical (muscular) in origin and results in physiological changes similar to those seen in acute inflammation, as well as in activation of polymorphonuclear neutrophils ${ }^{30}$. These polymorphonuclear neutrophils infiltrated in muscle damage sites release oxygen radicals and other reactive agents as part of the phagocytic process, leading to secondary tissue damage ${ }^{31}$. The infiltration of macrophages at the injury site rises steadily and is maintained through several days after exercise $^{32}$.

\section{- Conclusions}

The comet assay is a sensitive tool for assessing the effects of exercise during pregnancy on DNA damage and exercise has no adverse effects on both maternal and fetal health. In addition, no interference in body weight gain, pregnancy progress, delivery, and fetal viability were observed after treadmill training. However, an adequate intensity protocol is relevant to conduct an exercise program for laboratory animals and human.

\section{References}

1. Holemans K, Aerts L, Van Assche FA. Fetal growth restriction and consequences for the offspring in animal models. J Soc Gynecol Invest. 2003;10:392-99. doi: 10.1080/ jmf.11.4.254.257.

2. Kontic-Vucinic O, Terzic M, Radunovic N. The role of antioxidant vitamins in hypertensive disorders of pregnancy. J Perinat Med. 
2008;36(4):282-90. doi: 10.1515/ JPM.2008.063.

3. Skoner JM, Sigmon J, Larcom LL. Suppressed DNA repair capacity of peripheral lymphocytes in pregnant women. Mol Cell Endocrinol. 1995;108(1-2):179-83. PMID: 7758833.

4. Furnessa DLF, Dekkerb GA, Robertsa CT. DNA damage and health in pregnancy. J Reprod Immunol. 2011;89:153-62. doi: 10.1016/j. jri.2011.02.004.

5. Melzer K, Schutz $Y$, Boulvain $M$, Kayser B. Physical activity and pregnancy: cardiovascular adaptations, recommendations and pregnancy outcomes. Sports Med. 2010;40(6):493507. doi: 10.2165/11532290-00000000000000.

6. Weissgerber TL., Wolfe LA, Davies GA, Mottola MF. Exercise in the prevention and treatment of maternal-fetal disease: a review of the literature. Appl Physiol Nutr Metab. 2006;31(6):661-74. doi: 10.1139/ h06-060.

7. ACOG Practice Bulletin. Chronichypertension in pregnancy. ACOG Committee on Practice Bulletins. Obstet Gynecol. 2001;98(1):17785. PMID: 11508256.

8. Cash SW, Beresford SAA, Vaughan TL, Heagerty PJ, Bernstein L, White E, Neuhouser ML. Recent physical activity in relation to DNA damage and repair using the comet assay. J Phys Act Health. 2014;11(4):770-6. doi: 10.1123/jpah.2012-0278.

9. Matsuzaki M, Haruna M, Ota E, Murayama R, Yamaguchi T, Shioji I, Sasaki S, Yamaguchi $T$, Murashima S. Effects of lifestyle factors on urinary oxidative stress and serum antioxidant markers in pregnant Japanese women: a cohort study. Biosci Trends. 2014;8(3):176-84. PMID: 25030853.

10.Rodrigues B, Figueroa DM, Mostarda $\mathrm{CT}$, Heeren MV, Irigoyen MC, Angelis K. Maximal exercise test is a useful method for physical capacity and oxygen consumption determination in streptozotocin-diabetic rats. Cardiovasc Diabetol. 2007;6:38. doi: 10.1186/1475-2840-6-38.

11. Melo RM, Martinho E Jr, Michelini JC. Training-induced, pressure-lowering effect in SHR wide effects on circulatory profile of exercised and nonexercised muscles. Hypertension. 2003;42(2):851-7. doi: 10.1161/01.HYP.0000086201.27420.33.
12. Collins AR. The comet assay for DNA damage and repair: principles, applications, and limitations. Mol Biotechnol. 2004;26(3):24961. doi: $10.1385 / \mathrm{MB}: 26: 3: 249$.

13. Blasiak J, Arabski M, Krupa R,Wozniak K, Zadrozny M, Kaznicki J, Zurawska M, Drzewoski J. DNA damage and repair in type 2 diabetes mellitus. Mutat Res. 2004;554(1-2):297-304. doi: 10.1016/j. mrfmmm.2004.05.011.

14.Tice RR, Agurell $E$, Anderson $D$, Burlinson B, Hartmann A, Kobayashi H, Miyamae $Y$, Rojas E, Ryu JC, Sasaki YF. Single cell gel/ comet assay: guidelines for in vitro and in vivo genetic toxicology testing. Environ Mol Mutagen2000;35:206-21. PMID: 10737956.

15. Lima PHO, Damasceno DC, Sinzato YK, Souza MSS, Salvadori, Calderon IMP, Rudge MVC. Levels of DNA damage in blood leukocyte samples from non-diabetic and diabetic female rats and their fetuses exposed to air or cigarette smoke. Mutat Res. 2008;65:449. doi: 10.1016/j.mrgentox.2008.02.008.

16. Robinson AM, Bucci DJ. Physical exercise during pregnancy improves object recognition memory in adult offspring. Neuroscience. 2014;3;256:53-60. doi: 10.1016/j.neuroscience.2013.10.012.

17. Kim K, Chung E, Kim CJ, Lee S. Swimming exercise during pregnancy alleviates pregnancy-associated long-term memory impairment. Physiol Behav. 2012;107(1):826. doi: 10.1016/j.physbeh.2012.06.004.

18. Pereira BC, Pauli JR, Antunes LM, de Freitas $E C$, de Almeida $M R$, de Paula Venâncio $V$, Ropelle ER, de Souza CT, Cintra DE, Papoti $M$, da Silva AS. Overtraining is associated with DNA damage in blood and skeletal muscle cells of Swiss mice. BMC Physiol. 2013;13:11. doi: 10.1186/1472-6793-13-11.

19.Turgut S, Kaptanoğlu B, Emmungil G, Turgut G. Increased plasma levels of growth hormone, insulin-like growth factor (IGF)-I and IGF-binding protein 3 in pregnant rats with exercise. Tohoku J Exp Med. 2006;208(1):75-81. PMID: 16340176.

20.Piçarro IC, Barros Neto TL, De Teves DC, Silva AC, Denadai DS, Tarasantchi J, Russo AK.. Effect of exercise during pregnancy, graded as a percentage of aerobic capacity: maternal and fetal responses of the rat. Comp Biochem Physiol A Comp Physiol. 1991;100(4):795-9. PMID: 1685371.

21. Nagai A, Sakamoto K, Konno K. The effect 
of maternal exercise on somatic growth and lung development of fetal rats: morphologic and morphometric studies. Pediatr Pulmonol. 1993;15(6):332-8. PMID: 8337010.

22. Mottola MF, Bagnall KM, Belcastro AN. Effects of strenuous maternal exercise on fetal organ weights and skeletal muscle development in rats. J Dev Physiol. 1989;11(2):111-5. PMID: 2778291.

23. Veja CC, Reyes-Castro LA, Bautista CJ, Larrea $F$, Nathanielsz PW, Zambrano E. Exercise in obese female rats has beneficial effects on maternal and male and female offspring metabolism. Int J Obes (Lond). 2015 Apr;39(4):712-9. doi: 10.1038/ijo.2013.150.

24.Møller $P$, Knudsen LE, Loft S, Wallin $H$. The comet assay as a rapid test in biomonitoring occupational exposure to DNA-damaging agents and effect of confounding factors. Cancer Epidemiol Biomarkers Prev. 2000;9(10):1005-15. PMID: 11045781.

25.Petibois C, Cazorla G, Poortmans JR, Déléris G. Biochemical aspects of overtraining in endurance sports: the metabolism alteration process syndrome. Sports Med. 2003;33(2):83-94. PMID: 12617688.

26.Davison GW. Exercise and oxidative damage in nucleoid DNA quantified using single cell gel electrophoresis: present and future application. Front Physiol. 2016;7:249. doi: 10.3389/fphys.2016.00249.

27. Hamid NAA, Hasrul MA, Ruzanna RJ, Ibrahim IA, Baruah PS, Mazlan M, Yusof YA, Ngah WZ. Effect of vitamin $E$ (Tri $E^{\circledR}$ ) on antioxidant enzymes and DNA damage in rats following eight weeks exercise. Nutr J.
2011;10:37. doi: 10.1186/1475-2891-10-37. 28. Hartmann A, Plappert U, Raddatz K, Grunert-Fuchs M, Speit, G. Does physical activity induce DNA damage? Mutagenesis. 1994;9:269-72. PMID: 7934967.

29.Tsai K, Hsu TG, Hsu KM, Cheng H, Liu TY, Hsu CF, Kong CW. Oxidative DNA damage in human peripheral leukocytes induced by massive aerobic exercise. Free Radic Biol Med. 2001;31(11):1465-72. PMID: 11728819.

30.Benoni G, Bellavite P, Adami A, Chirumbolo S, Lippi G, Cuzzolin LB. Effect of acute exercise on some haematological parameters and neutrophil functions in active and inactive subjects. Eur J Appl Physiol Occup Physiol. 1995;70:187-91. PMID: 7768243.

31.Ebbeling CB, Clarkson PM. Exercise-induced muscle damage and adaptation. Sports Med. 1989;7:207-34. PMID: 2657962.

32.Smith LL. Acute inflammation: the underlying mechanism in delayed onset muscle soreness? Med Sci Sports Exerc. 1991;23:542-51. PMID: 2072832.

\section{- Acknowledgements}

The staff of Laboratory for Experimental Research in Gynecology and Obstetrics; to Mr. José Carlos Georgete, Mr. Mário Batista Bruno, Giovana Vesentini, Nathália Macedo and Thyego Santos for their technical contribution and to the Research Support Office of Botucatu Medical School, UNESP, especially Dr Jose Eduardo Corrente, for the statistical analysis.

\section{Correspondence:}

José Carlos Peraçoli

Universidade Estadual Paulista-Faculdade de

Medicina

Departamento de Ginecologia e Obstetrícia

Distrito de Rubião Júnior, s/n

18618-970 Botucatu - SP Brasil

Tel.: (55 14)3880-1386

mikaela.sicorrea@gmail.com.br

Received: Jan 09, 2017

Review: Mar 08, 2017

Accepted: Apr 10, 2017
Conflict of interest: none

Financial source: CAPES 